\title{
Greater Botryosphaeriaceae diversity in healthy than associated diseased Acacia karroo tree tissues
}

\author{
Fahimeh Jami • Bernard Slippers • \\ Michael J. Wingfield • Marieka Gryzenhout
}

Received: 22 August 2012 / Accepted: 5 March 2013 /Published online: 5 April 2013

(C) Australasian Plant Pathology Society Inc. 2013

\begin{abstract}
Botryosphaeriaceae are common endophytes of trees. Some species are also known to be pathogens. It is, therefore, assumed that endophytic Botryosphaeriaceae are often involved in general die-back diseases. Here we test this assumption in severe branch die-back observed on Acacia karroo trees in the Pretoria area of South Africa. The presence of the Botryosphaeriaceae was compared between healthy and diseased tissue on the same trees. Eight Botryosphaeriaceae species were isolated from die-back and healthy branches. Of these, six species, namely Tiarosporella urbis-rosarum, Diplodia allocellula, Phaeobotryosphaeria variabilis, Dothiorella brevicollis and Neofusicoccum vitifusiforme were obtained from healthy tissues, and only two species, Dothiorella dulcispinae and Spencermartinsia pretoriensis, were exclusively found in die-back branches. Spencermartinsia viticola was found in both tissue types and this fungus was also the most commonly isolated species from both healthy and die-back samples. Results of pathogenicity trials showed highly variable results for the isolated species and that the two species associated only with die-back symptoms, were weakly pathogenic. These results suggest that the
\end{abstract}

F. Jami $\cdot$ M. J. Wingfield

Department of Microbiology and Plant Pathology, Forestry \& Agricultural Biotechnology Institute (FABI), University of Pretoria, Pretoria, South Africa

\section{B. Slippers}

Department of Genetics, Forestry \& Agricultural Biotechnology Institute (FABI), University of Pretoria, Pretoria, South Africa

\section{Gryzenhout $(\bowtie)$}

Department of Plant Sciences, University of the Free State, Bloemfontein, South Africa

e-mail: Gryzenhoutm@ufs.ac.za
Botryosphaeriaceae found in these trees were not directly associated with the die-back symptoms, despite their diversity and common occurrence in these tissues. The situation is different in other tree systems where dominant species, often with wide host ranges, have been shown to be involved in die-back diseases. This indicates the importance of characterizing the unique aspects of each tree disease system.

Keywords Botryosphaeriaceae $\cdot$ Acacia karroo $\cdot$ Die-back · Diversity · South Africa

\section{Introduction}

Species residing in the fungal family Botryosphaeriaceae include latent pathogens that occur asymptomatically as endophytes for extended periods, but cause disease under stress conditions (Slippers and Wingfield 2007; Smith et al. 1996; Van Niekerk et al. 2011; Denman et al. 2000). Symptoms of these diseases include die-back followed by resin exudation, blackish discoloration of the heartwood and pith, fruit rot, leaf blight, premature leaf drop, gummosis and in severe cases tree death (Slippers et al. 2007; Slippers and Wingfield 2007). Some species of the Botryosphaeriaceae have wide host ranges and they also occur on all continents other than Antarctica (Slippers and Wingfield 2007; Taylor et al. 2009).

The pathogenicity of some Botryosphaeriaceae species has been well established, but the true role of most described species in disease is poorly studied. Many Botryosphaeriaceae have been isolated from die-back symptoms, others only from asymptomatic tissues and some have been found in both tissue types (Slippers and Wingfield 2007). When tested, many species have been shown to be pathogenic (Slippers and Wingfield 2007). For instance, species from die-back 
symptoms that have been shown to be aggressive pathogens in artificial inoculation trials include Diplodia africana on Juniperus phoenicea (Linaldeddu et al. 2012), Neofusicoccum parvum on Eucalyptus globulus (Iturritxa et al. 2011) and Syzygium paniculatum (Ploetz et al. 2009), Lasiodiplodia theobromae, L. pseudotheobromae and L. egyptiacae on Mangifera indica (Ismail et al. 2012) and Botryosphaeria dothidea, N. luteum, N. mediterraneum and N. parvum on Ficus microcarpa (Mayorquin et al. 2012). However, L. gonubiensis has been isolated from asymptomatic tissues of the native tree $S$. cordatum (Pavlic et al. 2004), but was also shown to cause lesions in pathogenicity trials (Pavlic et al. 2007). Several species have been isolated from both healthy and die-back. Lasiodiplodia theobromae were isolated from necrotic branches of Vaccinium species (Wright and Harmon 2009), vine die-back (Taylor et al. 2005; Van Niekerk et al. 2004) and healthy tissues of Terminalia catappa (Begoude et al. 2010) and Eucalyptus spp. (Pérez et al. 2010), while L. margaritacea were isolated from both healthy and die-back symptoms on native Adansonia gregorii (Pavlic et al. 2008; Sakalidis et al. 2011). All of these species were shown to be pathogenic in pathogenicity tests. The pathogenicity of some other Botryosphaeriaceae isolated from die-back symptoms, such as $N$. protearum from die-back of native Protea spp. (Denman et al. 2003), Spencermartinsia viticola and Dothiorella iberica on grapevine in New South Wales and South Australia (Luque et al. 2005; Pitt et al. 2010) still remain unknown in plant pathogenicity tests. This matter is further complicated because many studies fail to clearly indicate whether isolates have been obtained as endophytes or from diseased tissue.

Acacia karroo or sweet thorn (Fabales: Mimosoideae) is the most widespread native Acacia in southern Africa (Timberlake et al. 1999) and plays an important role in increasing soil fertility through nitrogen fixation with rhizobia nodules (Barnes et al. 1996). Die-back symptoms on branches of A. karroo are common in South Africa but they have become quite severe in the Pretoria area (Gauteng Province). Larval tunnels of an unidentified cerambycid beetle were sometimes observed in these dieback symptoms, and especially in the necrotic parts of the branch samples (Fig. 1). Cerambycid beetles have been reported from Acacia species in various parts of the world (Eisa and Roth 2009; Elliott and De Little 1985; Watt 1983). The larvae of cerambycid beetles (Coleoptera: Cerambycidae) are xylophagous and create a network of tunnels while feeding in different tissues of healthy, dead or decaying woody tissues of plants (Haack and Slansky 1987). Some cerambycid beetles can directly kill the trees or branches because their feeding in the cambium layers destroys the vascular tissues (Rad 2006; Hawkeswood 2011). These larvae could thus be involved in causing some of these symptoms or cause stress to the tree, but were not associated with them frequently enough to be the main causal agent.

Botryosphaeriaceae species are known to be associated with die-back symptoms on $A$. karroo and other Acacia trees in South Africa (Jami et al. 2012; Van der Walt 2008), and could thus be associated with the increased die-back of $A$. karroo in the Pretoria area. The aim of this study was to determine whether these species of Botryosphaeriaceae are also present and associated with the striking branch die-back symptoms in Pretoria, which have not been sampled previously. Due to the endophytic nature of the Botryosphaeriaceae, species of these fungi would most likely be associated with branches. Species occurring in die-back branches were thus compared with those found in asymptomatic tissues to establish a better understanding of the diversity of species existing as endophytes on these trees, and their potential relationship with those involved in the die-back symptoms.

\section{Materials and methods}

\section{Collection of samples}

Samples were collected from $40 \mathrm{~A}$. karroo trees having branches with die-back at different locations in the greater Pretoria area, Gauteng Province. The die-back begins where leaves on branch tips begin to wilt, turn brown and die, but they remain attached to the plant resulting in "flagging" symptoms (Fig. 1). Other than wilting, no symptoms were observed on the leaves. Lesions were formed in the woody tissue, with dead tissue extending internally within branches and often associated with gum production on the outside of the branches. These lesions were clearly the cause of the dieback symptoms as the wilting only occurred to the terminal ends of these lesions and wilting due to problems at the roots were unlikely.

A single branch showing die-back with internal lesions and an asymptomatic branch were collected from each tree. The branch samples were placed in paper bags and transported to the laboratory. For endophyte isolations, a selected portion of each branch was cut into $0.5 \mathrm{~cm}$ and twelve pieces were randomly selected from each branch. From the die-back branches, the portions selected were taken from the border zone between healthy and discolored wood. All of these amounted to 480 pieces in total from dieback and 480 from healthy branches, which were surfacedisinfested in $10 \%$ hydrogen peroxide for $2 \mathrm{~min}$, and rinsed three times in sterile water. Representative samples from all branches were placed onto $2 \%$ malt extract agar (four pieces per plate) (Biolab, Midrand, South Africa). Pieces 
Fig. 1 a Acacia karroo tree with die-back branches (arrow). b Gummosis (arrow) on dieback branch. c Cerambycid larva (arrow) that are occasionally found within a die-back branch
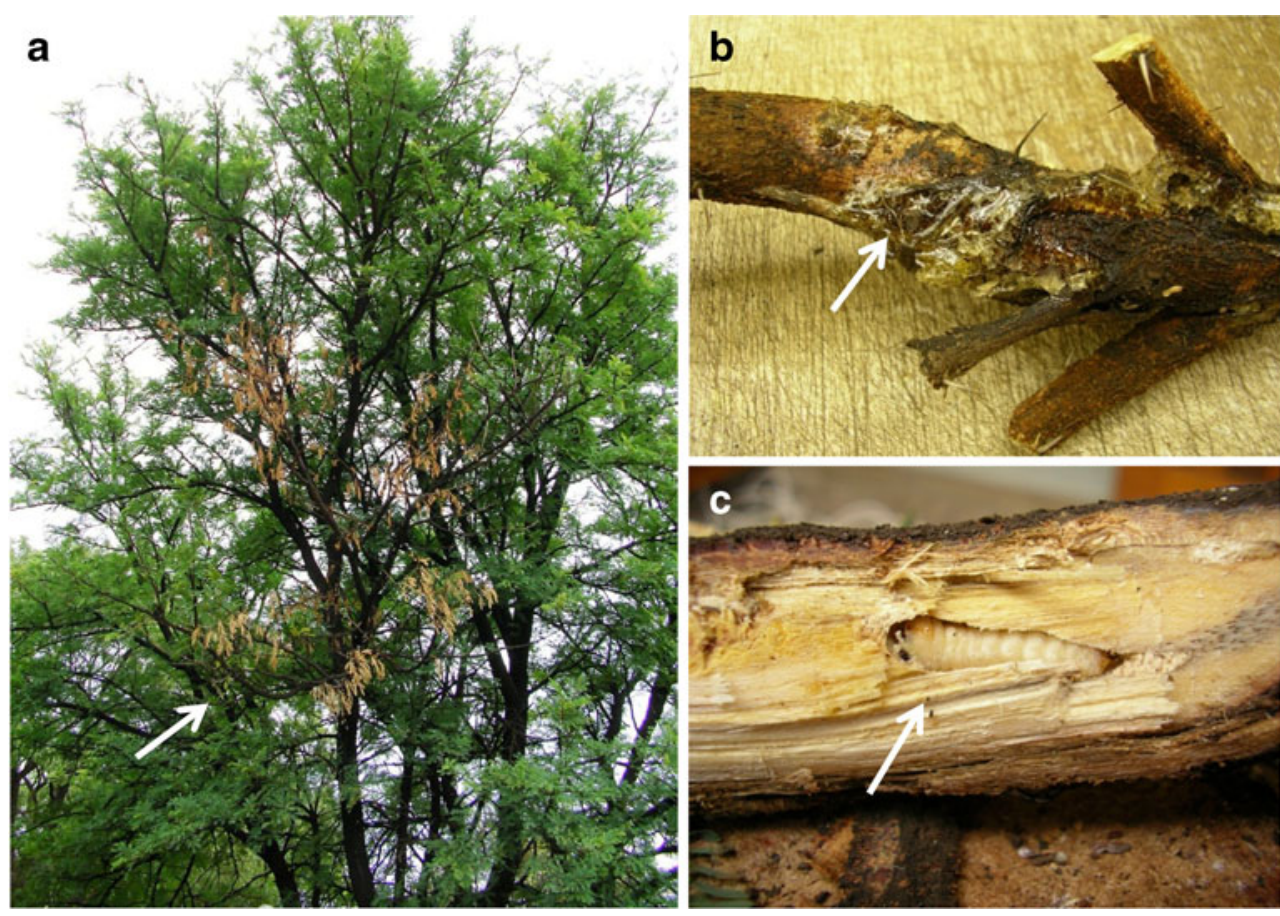

from diseased tissue were thus also placed onto agar selective for Phytophthora (NARPH) (Shearer and Dillon 1995) and between two slices of carrot for the isolation of Ceratocystis species (Moller and Devay 1968).

The plates and carrot pieces were incubated at $24{ }^{\circ} \mathrm{C}$ for 7 days and the fungal growth from each wood sample showing morphology characteristic of the Botryosphaeriaceae was transferred from the primary isolations to new MEA plates. After 4-5 days, all those isolates showing typical fast growing, white to black cultures with fluffy aerial hyphae were transferred to $15 \%$ WA (water agar) in order to make single hyphal tip sub-cultures. These isolates are maintained in the Culture Collection (CMW) of the Forestry and Agricultural Biotechnology Institute (FABI), University of Pretoria, Pretoria, South Africa.

\section{DNA sequence analyses}

Isolates (Table 1) were initially grouped based on culture morphology (fast growing, white to black cultures with aerial hyphae). DNA was extracted from the mycelium of 5-day-old single hyphal-tip cultures (Lee and Taylor 1990) representing three cultures for each morphological group. Sequence data were obtained for the internal transcribed spacer region of the ribosomal RNA (rRNA) operon using primers ITS-1 (Gardes and Bruns 1993) and ITS-4 (White et al. 1990), the $\beta$-tubulin gene using primers $\mathrm{Bt} 2 \mathrm{a}$ and $\mathrm{Bt} 2 \mathrm{~b}$ (Glass and Donaldson 1995), the translation elongation factor $1-\alpha$ (TEF- $1 \alpha$ ) gene using primers EF1-728F and EF1-986R (Carbone and Kohn 1999) and the large subunit rDNA (LSU) gene region using primers LR0 and LR5 (Vilgalys and Hester 1990).

The PCR reaction mixture, PCR conditions and visualization were as described by Jami et al. (2012). The amplified PCR fragments were purified with Sephadex (Sigma, Steinheim, Germany) and sequenced with the BigDye terminator cycle sequencing kit (Perkin-Elmer Applied Biosystems, Foster City, California, USA) in both directions, with the same primers used for the PCR reactions. PCR products were sequenced using an ABI 373048 capillary sequencer (Perkin-Elmer Applied Biosystems).

Sequences of the isolates were edited using Vector NTI 11 (Lu and Moriyama 2004). DNA sequences for relevant Botryosphaeriaceae species previously published were retrieved from GenBank (http://www.ncbi.nlm.gov). The resulting data matrices for each gene region were rooted with Pseudofusicoccum stromaticum following the example of Phillips et al. (2008). The data matrices were aligned online using MAFFT (http://align.bmr.kyushuu.ac.jp/mafft/ online/server/) version 6 (Katoh et al. 2005) and checked manually for alignment errors.

Phylogenetic analyses of sequence data for Maximum Parsimony (MP) and Maximum Likelihood (ML) were made using PAUP* v.4.0b10 (Swofford 2001). Maximum parsimony (MP) genealogies for single genes were constructed with the heuristic search option (100 random taxa additions, tree bisection and reconstruction or TBR in PAUP). The uninformative aligned regions within each dataset were removed from the analyses, gaps were treated as fifth character and all characters were unordered and of equal weight. Branches of zero length 
Table 1 Representative isolates from Acacia karroo used in the phylogenetic analyses

\begin{tabular}{|c|c|c|c|c|c|c|c|c|c|}
\hline \multirow[t]{2}{*}{ Isolate No. } & \multirow[t]{2}{*}{ Identity } & \multirow[t]{2}{*}{ Host } & \multirow[t]{2}{*}{ Location } & \multirow[t]{2}{*}{ Symptoms } & \multirow[t]{2}{*}{ Collector } & \multicolumn{4}{|l|}{ GenBank } \\
\hline & & & & & & ITS & EF1- $\alpha$ & LSU & $\beta$-tubulin \\
\hline CMW37928 & $\begin{array}{l}\text { Spencermartinsia } \\
\text { viticola }\end{array}$ & Tree no. 6 & $\begin{array}{l}\text { Pretoria, South } \\
\text { Africa }\end{array}$ & Healthy & $\begin{array}{l}\text { F. Jami \& M. } \\
\text { Gryzenhout }\end{array}$ & JX283730 & JX283741 & JX456000 & JX283717 \\
\hline CMW37929 & S. viticola & Tree no. 22 & $\begin{array}{l}\text { Pretoria, South } \\
\text { Africa }\end{array}$ & Healthy & $\begin{array}{l}\text { F. Jami \& M. } \\
\text { Gryzenhout }\end{array}$ & JX283731 & JX283744 & JX456001 & JX283720 \\
\hline CMW37930 & S. viticola & Tree no. 19 & $\begin{array}{l}\text { Pretoria, South } \\
\text { Africa }\end{array}$ & Healthy & $\begin{array}{r}\text { F. Jami \& M. } \\
\text { Gryzenhout }\end{array}$ & JX283732 & JX283745 & JX456002 & JX283721 \\
\hline CMW37931 & S. viticola & Tree no. 34 & $\begin{array}{l}\text { Pretoria, South } \\
\text { Africa }\end{array}$ & Die-back & $\begin{array}{l}\text { F. Jami \& M. } \\
\text { Gryzenhout }\end{array}$ & JX283733 & JX283742 & JX456003 & JX283716 \\
\hline CMW37932 & S. viticola & Tree no.33 & $\begin{array}{l}\text { Pretoria, South } \\
\text { Africa }\end{array}$ & Die-back & $\begin{array}{r}\text { F. Jami \& M. } \\
\text { Gryzenhout }\end{array}$ & JX283734 & JX283743 & JX456004 & JX283718 \\
\hline CMW37933 & S. viticola & Tree no.1 & $\begin{array}{l}\text { Pretoria, South } \\
\text { Africa }\end{array}$ & Die-back & $\begin{array}{r}\text { F. Jami \& M. } \\
\text { Gryzenhout }\end{array}$ & JX283735 & JX283745 & JX45599 & JX283719 \\
\hline CMW36463 & $\begin{array}{l}\text { Dothiorella } \\
\text { brevicollis }\end{array}$ & Tree no.6 & $\begin{array}{l}\text { Pretoria, South } \\
\text { Africa }\end{array}$ & Healthy & $\begin{array}{l}\text { F. Jami \& M. } \\
\text { Gryzenhout }\end{array}$ & JQ239403 & JQ239390 & JQ239416 & JQ239371 \\
\hline CMW36464 & Do. brevicollis & Tree no.38 & $\begin{array}{l}\text { Pretoria, South } \\
\text { Africa }\end{array}$ & Die-back & $\begin{array}{l}\text { F. Jami \& M. } \\
\text { Gryzenhout }\end{array}$ & JQ239404 & JQ239391 & JQ239417 & JQ239372 \\
\hline CMW36460 & $\begin{array}{l}\text { Dothiorella } \\
\text { dulcispinae }\end{array}$ & Tree no.39 & $\begin{array}{l}\text { Pretoria, South } \\
\text { Africa }\end{array}$ & Die-back & $\begin{array}{r}\text { F. Jami \& M. } \\
\text { Gryzenhout }\end{array}$ & JQ239400 & JQ239387 & JQ239413 & JQ239373 \\
\hline CMW36461 & Do. dulcispinae & Tree no. 12 & $\begin{array}{l}\text { Pretoria, South } \\
\text { Africa }\end{array}$ & Die-back & $\begin{array}{l}\text { F. Jami \& M. } \\
\text { Gryzenhout }\end{array}$ & JQ239401 & JQ239388 & JQ239414 & JQ239374 \\
\hline CMW36462 & Do. dulcispinae & Tree no. 14 & $\begin{array}{l}\text { Pretoria, South } \\
\text { Africa }\end{array}$ & Healthy & $\begin{array}{r}\text { F. Jami \& M. } \\
\text { Gryzenhout }\end{array}$ & JQ239402 & JQ239389 & JQ239415 & JQ239375 \\
\hline CMW36480 & $\begin{array}{l}\text { Spencermartinsia } \\
\text { pretoriensis }\end{array}$ & Tree no. 34 & $\begin{array}{l}\text { Pretoria, South } \\
\text { Africa }\end{array}$ & Die-back & $\begin{array}{l}\text { F. Jami \& M. } \\
\text { Gryzenhout }\end{array}$ & JQ239405 & JQ239392 & JQ239418 & JQ239376 \\
\hline CMW36481 & S. pretoriensis & Tree no.36 & $\begin{array}{l}\text { Pretoria, South } \\
\text { Africa }\end{array}$ & Die-back & $\begin{array}{l}\text { F. Jami \& M. } \\
\text { Gryzenhout }\end{array}$ & JQ239406 & JQ239393 & JQ239419 & JQ239377 \\
\hline CMW37934 & $\begin{array}{l}\text { Neofusicoccum } \\
\text { vitifusiforme }\end{array}$ & Tree no. 35 & $\begin{array}{l}\text { Pretoria, South } \\
\text { Africa }\end{array}$ & Healthy & $\begin{array}{l}\text { F. Jami \& M. } \\
\text { Gryzenhout }\end{array}$ & JX283728 & JX283746 & JX456005 & JX283722 \\
\hline CMW37935 & N. vitifusiforme & Tree no.14 & $\begin{array}{l}\text { Pretoria, South } \\
\text { Africa }\end{array}$ & Healthy & $\begin{array}{l}\text { F. Jami \& M. } \\
\text { Gryzenhout }\end{array}$ & JX283729 & JX283747 & JX456006 & JX283723 \\
\hline CMW36482 & $\begin{array}{l}\text { Phaeobotryosphaeria } \\
\text { variabilis }\end{array}$ & Tree no. 21 & $\begin{array}{l}\text { Pretoria, South } \\
\text { Africa }\end{array}$ & Healthy & $\begin{array}{r}\text { F. Jami \& M. } \\
\text { Gryzenhout }\end{array}$ & JX283726 & JX283738 & JX456007 & JX283714 \\
\hline CMW36483 & P. variabilis & Tree no. 23 & $\begin{array}{l}\text { Pretoria, South } \\
\text { Africa }\end{array}$ & Healthy & $\begin{array}{l}\text { F. Jami \& M. } \\
\text { Gryzenhout }\end{array}$ & JX283727 & JX283739 & JX456008 & JX283715 \\
\hline CMW36468 & Diplodia allocellula & Tree no. 7 & $\begin{array}{l}\text { Pretoria, South } \\
\text { Africa }\end{array}$ & Healthy & $\begin{array}{l}\text { F. Jami \& M. } \\
\text { Gryzenhout }\end{array}$ & JQ239397 & JQ239384 & JQ239410 & JQ239378 \\
\hline CMW36469 & D. allocellula & Tree no. 8 & $\begin{array}{l}\text { Pretoria, South } \\
\text { Africa }\end{array}$ & Healthy & $\begin{array}{l}\text { F. Jami \& M. } \\
\text { Gryzenhout }\end{array}$ & JQ239398 & JQ239385 & JQ239411 & JQ239379 \\
\hline CMW36470 & D. allocellula & Tree no. 9 & $\begin{array}{l}\text { Pretoria, South } \\
\text { Africa }\end{array}$ & Healthy & $\begin{array}{l}\text { F. Jami \& M. } \\
\text { Gryzenhout }\end{array}$ & JQ239399 & JQ239386 & JQ239412 & JQ239380 \\
\hline CMW36465 & $\begin{array}{l}\text { Tiarosporella } \\
\text { urbis-rosarum }\end{array}$ & Tree no. 4 & $\begin{array}{l}\text { Pretoria, South } \\
\text { Africa }\end{array}$ & Healthy & $\begin{array}{l}\text { F. Jami \& M. } \\
\text { Gryzenhout }\end{array}$ & JX283736 & JX283748 & JX45597 & JX283724 \\
\hline CMW36466 & T. urbis-rosarum & Tree no. 5 & $\begin{array}{l}\text { Pretoria, South } \\
\text { Africa }\end{array}$ & Healthy & $\begin{array}{r}\text { F. Jami \& M. } \\
\text { Gryzenhout }\end{array}$ & JX283737 & JX283749 & JX45598 & JX283725 \\
\hline CMW36479 & T. urbis-rosarum & Tree no. 3 & $\begin{array}{l}\text { Pretoria, South } \\
\text { Africa }\end{array}$ & Healthy & $\begin{array}{r}\text { F. Jami \& M. } \\
\text { Gryzenhout }\end{array}$ & JQ239409 & JQ239396 & JQ239422 & JQ239383 \\
\hline
\end{tabular}

were collapsed and all multiple, equally parsimonious trees were saved. The robustness of the tree(s) obtained was evaluated by 1,000 bootstrap replications. Congruence between the different datasets was tested using the Partition Homogeneity Test (PHT) in PAUP (Phylogenetic Analysis Using Parsimony) version 4.0b10 (Farris et al. 1995; Huelsenbeck et al. 1996), with the uninformative characters removed before analysis. Other measures such as tree length (TL), consistency index
(CI), rescaled consistency index (RC), and the retention index (RI) (Hillis and Huelsenbeck 1992) were recorded.

For ML analyses, the best nucleotide substitution models for each dataset were found separately with Modeltest 3.7 (Posada and Buckley 2004). All three datasets best fitted the GTR model with the ITS, TEF- $1 \alpha, \beta$-tubulin and combined datasets having the following parameters: for ITS $G=0.337, I=0.468$; for $T E F-1 \alpha G=0.819, I=0.759$; 
for $\beta$-tubulin $G=0.246, I=0$; for $L S U G=0.310$, $I=0$ and for combined datasets $G=0.318, I=0.436$. The analyses were performed in PAUP $4.0 \mathrm{~b} 10$ and confidence levels were determined with 1,000 bootstrap replications.

\section{Pathogenicity tests}

One-year-old $A$. karroo seedlings with stems ranging in height from $70-110 \mathrm{~cm}$ and $0.7-1.5 \mathrm{~cm}$ in diameter, and growing in a 1:2:4 mixture of river sand, red top soil and pine bark potting soil in 5-L plastic bags, were maintained in a greenhouse at $26{ }^{\circ} \mathrm{C}$ and watered once each day. Two to three isolates of each Botryosphaeriaceae species were randomly selected and each isolate was inoculated into 10 trees with one additional tree in each replication inoculated as a control. In total, 23 isolates were inoculated into 230 plants, totaling to 253 plants including the plants inoculated as negative controls.

For inoculation, a section of bark was removed from the main stems of the seedlings $15 \mathrm{~cm}$ above the soil level with a $6 \mathrm{~mm}$ sterilized cork-borer to expose the cambium. A $6 \mathrm{~mm}$ plug of agar, covered with mycelium of the test fungus, was placed with the mycelium surface facing inwards onto the wound, while clean agar discs were used in control inoculations. The inoculated wounds were sealed with Parafilm to minimize contamination and to prevent desiccation of the inoculum. Lesion lengths were measured 6 weeks after inoculation. Variation in the extent of the lesions was analyzed through a one-way analysis of variance (Karadzic 2003) with the general linear model procedure from SAS (version 9.3).

To re-isolate the inoculated fungi in order to confirm Koch's postulates, one plant was chosen from those inoculated for each isolate (in total 23 plants) and from the controls of each species (in total 8 plants). These were identified based on the conidial morphology. A small sample of tissue was cut from the lesions, including the inoculation points, surface disinfested with $10 \%$ hydrogen peroxide for $2 \mathrm{~min}$, and rinsed three times in sterile water. The tissue samples were plated onto $2 \%$ malt extract agar and incubated at $24{ }^{\circ} \mathrm{C}$ for 7 days.

\section{Results}

Collection of samples

In total 164 Botryosphaeriaceae isolates were isolated from A. karroo branches. Of these 84 isolates were from the 480 healthy wood pieces and 80 isolates were from the equivalent number of wood pieces displaying die-back symptoms. At least $50 \%$ of sampled trees yielded isolates and these were from across the geographical range sampled. No isolates of Ceratocystis or Phytophthora were obtained in this study.

DNA sequence analyses

The datasets for the ITS, TEF- $1 \alpha$ and $\beta$-tubulin sequences were analyzed individually and in combination. The ITS sequence dataset contained 546 characters (4 parsimonyuninformative, 148 parsimony-informative, 370 constant characters) with $\mathrm{CI}=0.602, \mathrm{RI}=0.902, \mathrm{RC}=0.543, \mathrm{HI}=$ 0.398 and $\mathrm{TL}=321$. The TEF- $1 \alpha$ dataset contained 362 characters ( 3 parsimony-uninformative, 224 parsimonyinformative, 135 constant characters) with $\mathrm{CI}=0.651, \mathrm{RI}=$ 0. $919, \mathrm{RC}=0.550, \mathrm{HI}=0.383$ and $\mathrm{TL}=986$. The $\beta$-tubulin dataset contained 471 characters ( 0 parsimony-uninformative, 142 parsimony-informative, 329 constant characters) with $\mathrm{CI}=0.698, \mathrm{RI}=0.901, \mathrm{RC}=0.629, \mathrm{HI}=0.302$, and $\mathrm{TL}=304$. The LSU dataset contained 845 characters $(7$ parsimonyuninformative, 72 parsimony-informative and 766 constant characters) with $\mathrm{CI}=0.642, \mathrm{RI}=0.875, \mathrm{RC}=0.587, \mathrm{HI}=$ 0.328 and $\mathrm{TL}=138$. The tree statistics for the combined dataset (TreeBase Accession No. S12358) were CI $=0.487$, $\mathrm{RI}=0.854, \mathrm{RC}=0.416, \mathrm{HI}=0.513, \mathrm{TL}=2,148$, and the partition homogeneity test (PHT) on the datasets produced a P-value of 0.01 .

The topology of the trees obtained using the ML and MP analyses were similar for the individual gene regions, as well as in the combined analysis with regards to the clades representing species isolated in this study. However, clades representing genera occasionally collapsed in individual analyses. Isolates resided in five genera and eight species that were identified as follows: Spencermartinsia pretoriensis, S. viticola, Dothiorella dulcispinae, Do. brevicollis, Diplodia allocellula, Phaeobotryosphaeria variabilis, Tiarosporella urbis-rosarum and Neofusicoccum vitifusiforme (Fig. 2).

Of the eight Botryosphaeriaceae species, $S$. viticola was most common and dominant in both healthy and die-back tissue. Of total isolates, $77.3 \%$ represented $S$. viticola, $2.3 \%$ Do. brevicollis, $9.5 \%$ D. allocellula, $3.5 \%$ P. variabilis, $3.5 \%$ T. urbis-rosarum and $3.5 \% N$. vitifusiforme (Table 1 ). The isolates of Spencermartinsia pretoriensis (CMW36480 and CMW36481), Dothiorella dulcispinae (CMW36460, CMW36461 and CMW36462) and S. viticola (CMW37931, CMW37932 and CMW37933) were representative of isolates from branches with die-back $(2.5 \% S$. pretoriensis, $10 \%$ Do. dulcispinae and $87.5 \%$ S. viticola) (Table 1). Representative isolates from healthy branches included S. viticola (CMW37928, CMW37929 and CMW37930), Do. brevicollis (CMW36464 and CMW 36463), Diplodia allocellula (CMW36468, CMW36469 and CMW36470), Phaeobotryosphaeria variabilis 


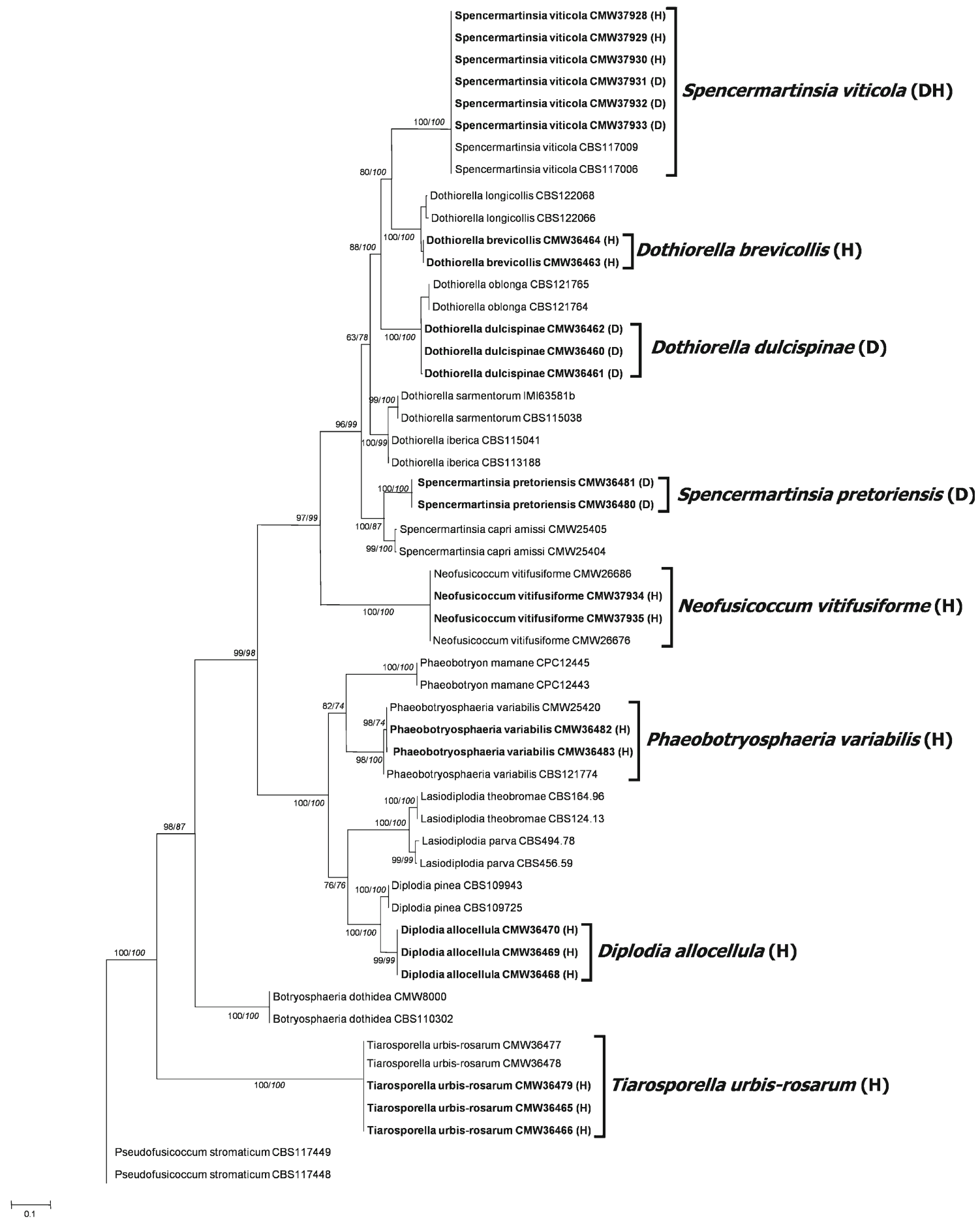

Fig. 2 Maximum Likelihood (ML) tree of the combined data set of ITS ribosomal DNA, TEF- $1 \alpha, \beta$-tubulin and LSU gene region sequences. Bootstrap values for ML (Piano et al. 2005) and Maximum Parsimony (italic) above $60 \%$ are given at the nodes. The tree was

(CMW36482, CMW36483), Tiarosporella urbis-rosarum (CMW36479, CMW36465 and CMW36466) and Neofusicoccum vitifusiforme (CMW37934, CMW37935). Some isolates were obtained from the same tree such as those of Do. brevicollis (CMW 36463) and $S$. rooted to Pseudofusicoccum stromaticum (CBS117448 and CBS117449). $\mathrm{H}=$ Isolates from healthy branches, $\mathrm{D}=$ Isolates from die-back branches

viticola (CMW37928), S. viticola (CMW37931) and S. pretoriensis (CMW36480), and Do. dulcispinae (CMW36462) and $N$. vitifusiforme (CMW37935), respectively (Table 1). The rest of the isolates were obtained from different trees. 

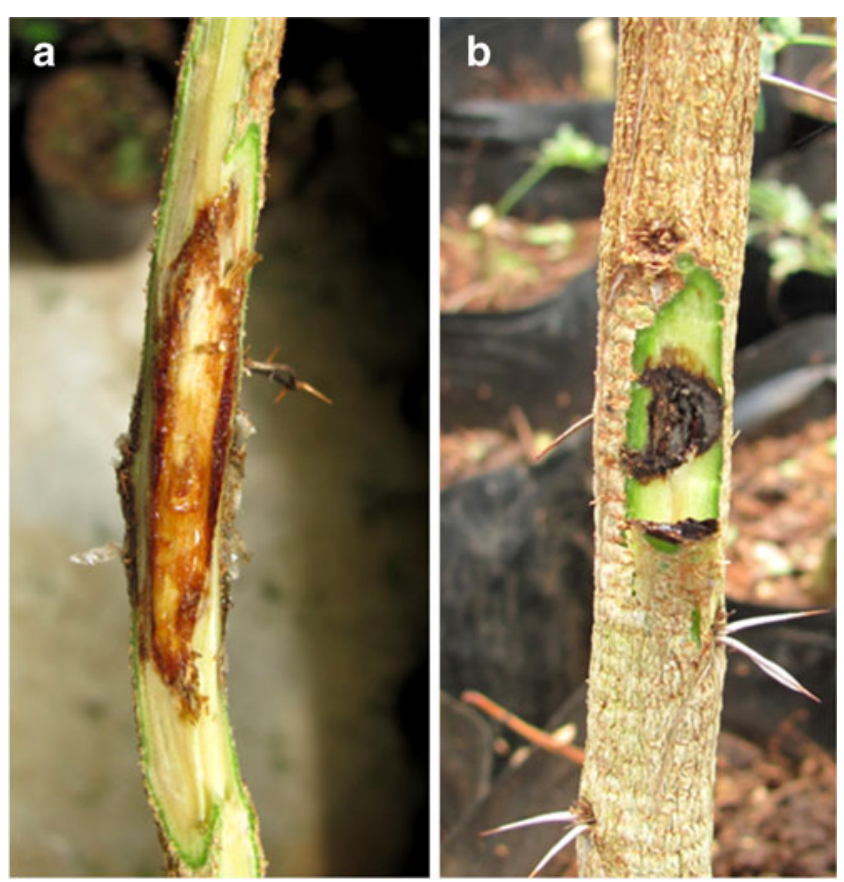

Fig. 3 (a) Stem of seedling with a distinct lesion resulting from inoculation with Phaeobotryosphaeria variabilis. (b) Seedling inoculated as a control with no evidence of lesion development
Pathogenicity tests

All 23 isolates of the eight species produced lesions in the cambium of inoculated branches within 6 weeks (Fig. 3), and the average lesions length were significantly $(P<0.05)$ larger than those observed for the controls. Statistical analyses showed that lesion sizes varied little between the ten inoculated trees for each isolate, but did vary considerably between the isolates used for some species, namely $D o$. brevicollis, T. urbis-rosarum and S. viticola. The longest lesions were produced by isolates of $P$. variabilis (average lesion length $30.5 \mathrm{~mm}$ ), one isolate of Do. brevicollis (average lesion length $17 \mathrm{~mm}$ ), one isolate of $S$. viticola (average lesion length $12 \mathrm{~mm}$ ) and one isolate of T. urbisrosarum (average lesion length $11 \mathrm{~mm}$ ). All these isolates were obtained from healthy tissues, even though the pathogenicity test showed that they were the most pathogenic isolates. Isolates obtained from die-back tissues represented some of the isolates producing the shortest lesions, namely isolates of $S$. pretoriensis (average lesion length $5 \mathrm{~mm}$ ) and Do. dulcispinae (average lesion length $8.5 \mathrm{~mm}$ ). Two isolates of $S$. viticola (average lesion length $5 \mathrm{~mm}$ ), of which one originated from die-back and another from healthy tissues, and two isolates of T. urbis-rosarum (average lesion length $4.5 \mathrm{~mm}$ ) that were both from healthy tissues (Fig. 4)

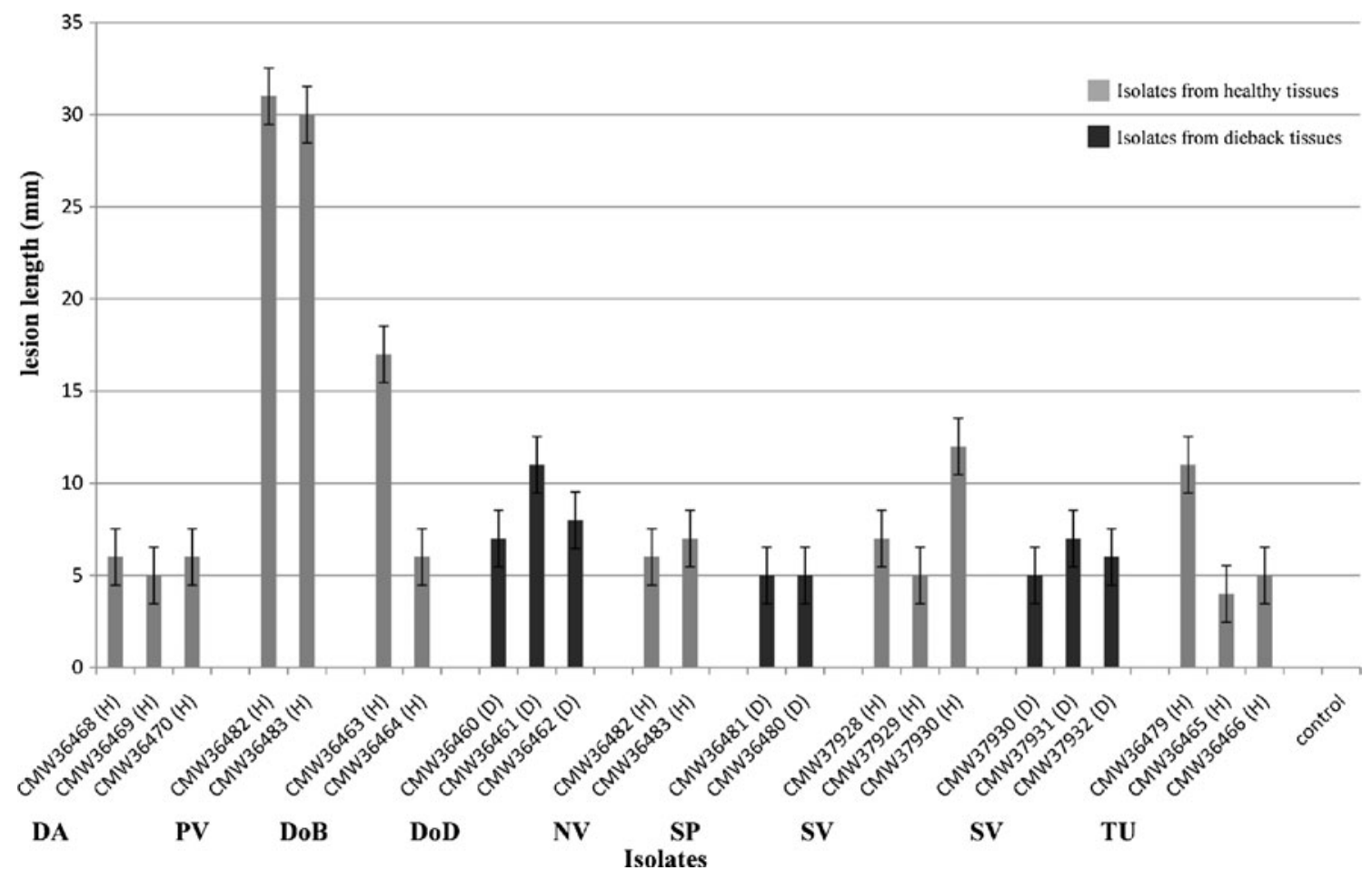

Fig. 4 Average length ( $\mathrm{mm})$ of lesions produced on Acacia karroo seedlings inoculated with 19 isolates of eight Botryosphaeriaceae species (isolates were obtained from healthy and diseased tissue) and a negative control after 5 weeks in a greenhouse. All isolates produced lesions significantly greater $(P<0.05)$ than those of the controls. $\mathrm{H}=$
Isolates from healthy branches, $\mathrm{D}=$ Isolates from die-back branches. DA Diplodia allocellula, PV Phaeobotryosphaeria variabilis, DoB Dothiorella brevicollis, DoD Do. dulcispinae, NV Neofusicoccum vitifusiforme, SP Spencermartinsia pretoriensis, SV S. viticola, TU Tiarosporella urbis-rosarum 
were among those isolates that produced the smallest lesions. All eight Botryosphaeriaceae species were re-isolated from lesions and no Botryosphaeriaceae were isolated from the controls.

\section{Discussion}

Eight species of Botryosphaeriaceae were isolated from branches of $40 \mathrm{~A}$. karroo trees, either healthy or displaying symptoms of die-back. Most of these species, including Tiarosporella urbis-rosarum, Diplodia allocellula, P. variabilis, Dothiorella brevicollis, Neofusicoccum vitifusiforme and Spencermartinsia viticola, were obtained from healthy tissues. In contrast, only three species, namely Dothiorella dulcispinae, S. pretoriensis and S. viticola, were isolated from die-back tissue. Thus only S. viticola occurred on both healthy and diseased tissue types and only two species, Do. dulcispinae and S. pretoriensis, were found exclusively in die-back tissue. A maximum of two species co-occurred in a single tree, including Do. brevicollis, $S$. viticola, S. pretoriensis, Do. dulcispinae and $N$. vitifusiforme.

All the isolated species of Botryosphaeriaceae produced lesions on inoculated A. karroo branches. Surprisingly, the two species found only in branches with die-back, namely $S$. pretoriensis and Do. dulcispinae, were among those producing the smallest lesions. These two species also represented only $12.5 \%$ of the total number of isolates from diseased tissue while $87.5 \%$ of isolates were those of $S$. viticola. These results suggest that the Botryosphaeriaceae isolated in this study play little if any role in the development of dieback symptoms on A. karroo.

Spencermartinsia viticola was isolated from both dieback and healthy tissue, and this species was also the most dominant species isolated. S. viticola was described for the first time from decline of Vitis vinifera in Spain as a saprophyte (Luque et al. 2005). However, since then it has been reported from diseases on many other plants such as warts on trunks of Populus cathayana in China (Zhang et al. 2009), canker of citrus in California (Adesemoye and Eskalen 2011) and from healthy tissues of Acacia mellifera in South Africa (Van der Walt 2008). The results of our study confirm that this species can produce lesions on A. karroo in pathogenicity tests, but it was amongst those producing fairly short lesions and this species thus does not appear to be a particularly aggressive pathogen on A. karroo.

In a previous study, Phaeobotryosphaeria variabilis was isolated from die-back branches on A. karroo, but its pathogenicity was not considered (Van der Walt 2008). In the present study, we found P. variabilis only in healthy tissues, but it produced the longest lesions of all the species in the pathogenicity trial. This species thus appears to have the capacity to cause disease on A. karroo, although it was apparently not involved with the die-back symptoms studied here.

Isolates of some species differed significantly in their aggressiveness in pathogenicity tests. For example, some isolates of T. urbis-rosarum, S. viticola and Do. brevicollis produced long lesions in the inoculation tests while the other isolates of these species were amongst those that produced small lesions. This could be due to genetic differences in the isolates themselves or differences in susceptibility of genotypes of seedlings, which is not unusual as it is known that isolates of species can differ considerably in their pathogenicity (Mayer 2006; Müller et al. 2001). Little variation was observed in our study between the trees inoculated with the particular isolates, and the variation observed thus appears linked to differences in virulence of the various isolates. This implies that due to these differences in virulence the most virulent isolates may not have been used for the pathogenicity tests, and that more virulent isolates for each species could occur in branches, contributing to die-back.

It is possible that the damage caused by the feeding cerambycid larvae or other biological agents places the branches under stress allowing endophytic, opportunistic Botryosphaeriaceae to have the opportunity to cause disease symptoms (Slippers and Wingfield 2007). Further studies will be necessary to determine if there is any direct association between the Botryosphaeriaceae species occurring naturally as endophytes in $A$. karroo and such other biological agents, or whether the presence of the Botryosphaeriaceae and possible die-back symptoms are only co-incidental and opportunistic. Such further studies would, for example, include determining whether these fungi are associated with the larvae, targeting development of lesions linked to earlier stages of beetle larval infestation, and considering possible transmission mechanisms by the beetles.

The results of this study emphasize the extensive diversity of the Botryosphaeriaceae community that can exist on trees in a limited area. Furthermore, these are all potential pathogens. Our study also elucidates the necessity to study each tree system separately to determine the ecological roles of the Botryosphaeriaceae found in the tree species, which may differ those in other tree systems. Expanding in depth sampling in particular areas, such as on more than one host, together with extensive pathogenicity studies will be very helpful to further characterize the potential role these fungi can play in disease of such native communities.

Acknowledgments We thank Ms. Kerry-Anne Pillay and Mr. James Mehl for assistance in collecting the samples, Dr. Mike van der Linde and Mr. Andre Swanepoel for providing help and advice with the statistical analyses. Members of the Tree Protection Cooperative Programme (TPCP), the DST/NRF Centre of Excellence in Tree Health Biotechnology (CTHB) and the University of Pretoria, South Africa, are acknowledged for financial support. 


\section{References}

Adesemoye A, Eskalen A (2011) First report of Spencermartinsia viticola, Neofusicoccum australe, and $N$. parvum causing branch canker of citrus in California. Plant Dis 95(6):770

Barnes R, Filer D, Milton S (1996) Acacia karroo. Monograph and annotated bibliography

Begoude BAD, Slippers B, Wingfield MJ, Roux J (2010) Botryosphaeriaceae associated with Terminalia catappa in Cameroon, South Africa and Madagascar. Mycol Prog 9(1):101-123

Carbone I, Kohn LM (1999) A method for designing primer sets for speciation studies in filamentous ascomycetes. Mycologia 91(3):553-556

Denman S, Crous PW, Taylor JE, Kang JC, Pascoe L, Wingfield MJ (2000) An overview of the taxonomic history of Botryosphaeria, and a re-evaluation of its anamorphs based on morphology and ITS rDNA phylogeny. Stud Mycol 45:129-140

Denman S, Crous PW, Groenewald JZ, Slippers B, Wingfield BD, Wingfield MJ (2003) Circumscription of Botryosphaeria species associated with Proteaceae based on morphology and DNA sequence data. Mycologia 95(2):294-307

Eisa MA, Roth M (2009) A survey of the longhorned beetles species (Cerambycidae) on Acacia trees in the Gum Arabic Belt of Sudan. Biophysical and socio-economic frame conditions for the sustainable management of natural resources October 6-8, 2009, Hamburg

Elliott H, De Little DW (1985) Insect pests of trees and timber in Tasmania. Forestry Commission, Hobart

Farris J, Kallersjo M, Kluge A, Bult C (1995) Testing significance of incongruence. Cladistics 10:315-319

Gardes M, Bruns T (1993) ITS primers with enhanced specificity for basidiomycetes-application to the identification of mycorrhizae and rusts. Mol Ecol 2(2):113-118

Glass NL, Donaldson GC (1995) Development of primer sets designed for use with the PCR to amplify conserved genes from filamentous ascomycetes. Appl Environ Microbiol 61(4):1323-1330

Haack R, Slansky FJ (1987) Nutritional ecology of wood-feeding Coleoptera, Lepidoptera, and Hymenoptera. Nutritional ecology of insects, mites, spiders, and related invertebrates. Wiley, New York, pp 449-486

Hawkeswood TJ (2011) Review of the biology and host plants of several species of Pterolophia Newman, 1842 (Coleoptera: Cerambycidae) from Papua New Guinea and the Solomon Islands. Calodema 164(1-4)

Hillis D, Huelsenbeck J (1992) Signal, noise, and reliability in molecular phylogenetic analyses. J Hered 83(3):189-195

Huelsenbeck JP, Bull JJ, Cunningham CW (1996) Combining data in phylogenetic analysis. Trends Ecol Evol 11(4):152-158

Ismail AM, Cirvilleri G, Polizzi G, Crous PW, Groenewald JZ, Lombard L (2012) Lasiodiplodia species associated with dieback disease of mango (Mangifera indica) in Egypt. Australas Plant Pathol 41:649-660

Iturritxa E, Slippers B, Mesanza N, Wingfield MJ (2011) First report of Neofusicoccum parvum causing canker and die-back of Eucalyptus in Spain. Australas Plant Dis Notes 6:57-59

Jami F, Slippers B, Wingfield M, Gryzenhout M (2012) Five new species of the Botryosphaeriaceae from Acacia karroo in South Africa. Cryptogam Mycol 33(3):245-266

Karadzic D (2003) Tiarosporella durmitorensis Karadzhic: distribution, description, epidemiology and impact in Yugoslavia. Proceedings of an international scientific conference marking 75 years of the Forest Research Institute of the Bulgarian Academy of Sciences, Sofia, Bulgaria 2:183-186

Katoh K, Kuma K, Toh H, Miyata T (2005) MAFFT version 5: improvement in accuracy of multiple sequence alignment. Nucleic Acids Res 33(2):511
Lee S, Taylor J (1990) Isolation of DNA from fungal mycelia and single spores. In: Innis MA, Gelfand DH, Sninsky JJ, White TJ (eds) PCR protocols. A guide to methods and applications. Academic, San Diego, pp 282-287

Linaldeddu B, Scanu B, Maddau L, Franceschini A (2012) Diplodia africana causing dieback disease on Juniperus phoenicea: a new host and first report in the northern hemisphere. Phytopathol Mediterr 50(3):473-477

Lu G, Moriyama EN (2004) Vector NTI, a balanced all-in-one sequence analysis suite. Brief Bioinform 5(4):378-388

Luque J, Martos S, Phillips AJL (2005) Botryosphaeria viticola sp. nov. on grapevines: a new species with a Dothiorella anamorph. Mycologia 97(5):1111-1121

Mayer A (2006) Pathogenesis by fungi and by parasitic plants: similarities and differences. Phytoparasitica 34(1):3-16

Mayorquin JS, Downer J, Hodel D, Liu A, Eskalen A (2012) First Report of Multiple Species of the Botryosphaeriaceae Causing Bot Canker Disease of Indian Laurel-Leaf Fig in California. Plant Dis 96(3):459

Moller WJ, Devay JE (1968) Carrot as a species-selective isolation medium for Ceratocystis fimbriata. Phytopathology 58:123-126

Müller MM, Valjakka R, Suokko A, Hantula J (2001) Diversity of endophytic fungi of single Norway spruce needles and their role as pioneer decomposers. Mol Ecol 10(7):1801-1810

Pavlic D, Slippers B, Coutinho TA, Gryzenhout M, Wingfield MJ (2004) Lasiodiplodia gonubiensis sp. nov., a new Botryosphaeria anamorph from native Syzygium cordatum in South Africa. Stud Mycol 50:313-322

Pavlic D, Slippers B, Coutinho TA, Wingfield MJ (2007) Botryosphaeriaceae occurring on native Syzygium cordatum in South Africa and their potential threat to Eucalyptus. Plant Pathol 56(4):624-636

Pavlic D, Wingfield MJ, Barber P, Slippers B, Hardy G, Burgess TI (2008) Seven new species of the Botryosphaeriaceae from baobab and other native trees in Western Australia. Mycologia 100(6):851-866

Pérez C, Wingfield M, Slippers B, Altier N, Blanchette R (2010) Endophytic and canker-associated Botryosphaeriaceae occurring on non-native Eucalyptus and native Myrtaceae trees in Uruguay. Fungal Divers 41(1):53-69

Phillips AJL, Alves A, Pennycook SR, Johnston PR, Ramaley A, Akulov A, Crous PW (2008) Resolving the phylogenetic and taxonomic status of dark-spored teleomorph genera in the Botryosphaeriaceae. Persoonia Mol Phylogeny Evol Fungi 21:29-55

Piano E, Bertoli F, Romani M, Tava A, Riccioni L, Valvassori M, Carroni A, Pecetti L (2005) Specificity of host-endophyte association in tall fescue populations from Sardinia, Italy. Crop Sci 45(4):1456-1463

Pitt W, Huang R, Steel C, Savocchia S (2010) Identification, distribution and current taxonomy of Botryosphaeriaceae species associated with grapevine decline in New South Wales and South Australia. Aust J Grape Wine Res 16(1):258-271

Ploetz R, Pérez-Martínez J, Palmateer A, Cating R (2009) Neofusicoccum parvum causes a lethal dieback of Syzygium paniculatum in Florida. Plant Pathol 58(4):801

Posada D, Buckley TR (2004) Model selection and model averaging in phylogenetics: advantages of Akaike information criterion and Bayesian approaches over likelihood ratio tests. Syst Biol 53(5):793-808

Rad HH (2006) Study on the biology and distribution of long-horned beetles Calchaenesthes pistacivora $\mathrm{n}$. sp. (Col.: Cerambycidae): a new pistachio and wild pistachio pest in Kerman province. IV International Symposium on Pistachios and Almonds, Teheran, Iran:425-430

Sakalidis M, Hardy G, Burgess T (2011) Endophytes as potential pathogens of the baobab species Adansonia gregorii: a focus on the Botryosphaeriaceae. Fungal Ecol 4:1-14 
Shearer BL, Dillon M (1995) Susceptibility of plant species in Eucalyptus marginata forest to infection by Phytophthora cinnamomi. Aust J Bot 43:113-134

Slippers B, Wingfield MJ (2007) Botryosphaeriaceae as endophytes and latent pathogens of woody plants: diversity, ecology and impact. Fungal Biol Rev 21(2-3):90-106

Slippers B, Smit WA, Crous PW, Coutinho TA, Wingfield BD, Wingfield MJ (2007) Taxonomy, phylogeny and identification of Botryosphaeriaceae associated with pome and stone fruit trees in South Africa and other regions of the world. Plant Pathol $56: 128-139$

Smith H, Wingfield MJ, Petrini O (1996) Botryosphaeria dothidea endophytic in Eucalyptus grandis and Eucalyptus nitens in South Africa. For Ecol Manage 89(1-3):189-195

Swofford DL (2001) PAUP. Phylogenetic analysis using parsimony (and other methods). Version 4. Sinaur Associates, Sunderland

Taylor A, Hardy G, Wood P, Burgess T (2005) Identification and pathogenicity of Botryosphaeria species associated with grapevine decline in Western Australia. Australas Plant Pathol 34(2):187-195

Taylor K, Barber PA, GE SJH, Burgess TI (2009) Botryosphaeriaceae from tuart (Eucalyptus gomphocephala) woodland, including descriptions of four new species. Mycol Res 113(3):337-353

Timberlake J, Fagg C, Barne RD (1999) Field guide to the Acacias of Zimbabwe. CBC Publishing, Harare, p 160
Van der Walt FJJ (2008) Botrosphaeriaceae associated with Acacia species in southern Africa with special reference to $A$. melifera. Masters Thesis, University of Pretoria: South Africa, $198 \mathrm{p}$

Van Niekerk JM, Crous PW, Groenewald JZ, Fourie PH, Halleen F (2004) DNA phylogeny, morphology and pathogenicity of Botryosphaeria species on grapevines. Mycologia 96(4):781-798

Van Niekerk J, Strever AE, Du Toit GP, Halleen F, Fourie PH (2011) Influence of water stress on Botryosphaeriaceae disease expression in grapevines. Phytopathol Mediterr 50(4):151-165

Vilgalys R, Hester M (1990) Rapid genetic identification and mapping of enzymatically amplified ribosomal DNA from several Cryptococcus species. J Bacteriol 172(8):4238-4246

Watt JC (1983) The huhu Prionoplus reticularis (Cerambycidae) and other Coleoptera in Acacia. N Z Entomol 7(4):365

White T, Bruns T, Lee S, Taylor J (1990) Amplification and direct sequencing of fungal ribosomal RNA genes for phylogenetics. In: Innis MA, Gelfand DH, Sninsky JJ, White TJ (eds) PCR protocols: a guide to methods and applications. Academic, New York, pp 315-322

Wright A, Harmon P (2009) First report of Lasiodiplodia theobromae associated with stem blight of southern highbush blueberries in Florida. Plant Dis 93(9):962

Zhang R, Guo X, Sun G, Tang M, Gleason ML (2009) Dothiorella viticola on Populus cathayana in China: a new record. Mycotaxon 109(1):129-135 